\title{
Assessing environmental initiatives through an ecosystem stewardship lens
}

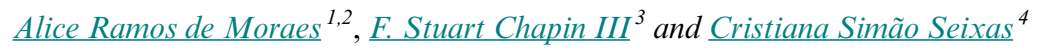

\begin{abstract}
Stewardship has been increasingly used in the realm of conservation and sustainable land use as an important pathway for action. Ecosystem stewardship, a specific application of this concept, is an approach for natural resource management, but the lack of empirical examples is a shortcoming to its applicability. With this work, we aimed at investigating whether environmental initiatives taking place in a rural watershed in southeast Brazil can be framed as ecosystem stewardship and, if so, whether they address key socialecological feedbacks that influence the quality of critical local ecosystem services (water, food production, soil, forests). Drawing on data from direct and participant observation at community and technical meetings, nine unstructured interviews, and gray literature, we demonstrated that three initiatives encompass all elements of ecosystem stewardship to some extent (dual goals of ecosystem resilience and human well-being, integration of processes across scales and emphasis on actions that shape the future). Only one initiative, a multi-stakeholder network, fully entails all elements of ecosystem stewardship. The initiatives overlap in space and time and entail pressing and non-urgent issues, therefore they promote, as a group, complementary ecosystem stewardship practices at various levels in the territory. They also address the key feedbacks responsible for the degradation of water, food production, and soil. Knowledge, relational values, and care are salient ingredients that combine in different ways, shaping each initiative. Our findings suggest that ecosystem stewardship arises from local social-ecological challenges combined with stakeholders' knowledge and understanding of the system dynamics. Collaboration among initiatives can strengthen their effects on undesired feedbacks and enable the design of joint strategies to tackle the erosion of relational values. Actions focusing on reconnecting local communities and forests may safeguard the flux of ecosystem-service bundles on both the short and long term.
\end{abstract}

Key Words: ecosystem services; local knowledge; natural resource management; relational values; rural landscape; social-ecological feedbacks

\section{INTRODUCTION}

Ecosystem stewardship is an approach to natural resource management that emerged from the urgent necessity for sustainability solutions encompassing both human needs and the conditions necessary for ecosystems to sustain their functioning and provision of services needed by society (Chapin et al. 2010). Humans are an integral part of social-ecological systems (Berkes and Folke 1998) and depend on natural ecosystems for survival, societal development, and well-being. Therefore, humans and other elements of nature cannot be considered conceptually distinct from one another (Saxena et al. 2018), and this perspective should be embedded in every approach and action of natural resource management.

As proposed by Chapin et al. (2010), ecosystem stewardship highlights the interdependence of human societies with natural ecosystems. It is an action-oriented framework designed "to respond to and shape social-ecological systems under conditions of uncertainty and change" whose central goal is "to sustain the capacity [of ecosystems] to provide ecosystem services that support human well-being" (Chapin et al. 2010:242). Built upon a social-ecological resilience approach, ecosystem stewardship focuses on managing stabilizing or amplifying feedbacks (Chapin et al. 2010). Still, there are relatively few empirical examples framed as ecosystem stewardship in the scientific literature. Therefore, research that elucidates how this is put into practice can guide the application of this framework.

In simple terms, the word stewardship means taking care of something (Chapin et al. 2015, Mathevet et al. 2018), and its use is rooted in cultural and religious traditions (Chapin et al. 2015). More recently, stewardship has gained acceptance in the arena of environmental management and conservation science, usually referring to a wide range of environmentally friendly actions and sustainable use of natural resources (Bennett et al. 2018, Mathevet et al. 2018, Peçanha Enqvist et al. 2018, West et al. 2018). Some examples are community-based forestry programs (Baynes et al. 2015), the design of local agri-environmental schemes (Raymond et al. 2016), community gardens, tree-planting initiatives, and conservation of urban green spaces (Krasny and Tidball 2012, Krasny et al. 2015).

This diversity of initiatives reflects different meanings of stewardship (Peçanha Enqvist et al. 2018) and proposed frameworks (Bennett et al. 2018, Peçanha Enqvist et al. 2018), as well as different underlying political ideologies and ethical values related to conservation actions and policies (Mathevet et al. 2018) Nevertheless, action, care, and knowledge are three concepts that permeate the different meanings of stewardship in the scientific literature (Peçanha Enqvist et al. 2018). A relational understanding of care within stewardship has been recently developed (Jax et al. 2018, West et al. 2018), opening new possibilities for interpreting and understanding how stewardship action comes to life (West et al. 2018). Relational values are those where the relationship itself matters (Chan et al. 2018), and in this context, they refer to the responsibilities and interactions that people have with other elements of nature or with other people, in a particular place (Chan et al. 2016, 2018). This concept encompasses elements present in the relationship between humans and other elements of nature that transcend the limits of

${ }^{1}$ Graduate Program in Ecology at the Institute of Biology, University of Campinas (UNICAMP), ${ }^{2}$ Ecosystem Ecology and Management Lab at the Environmental Studies and Research Center (NEPAM), University of Campinas (UNICAMP), ${ }^{3}$ Institute of Arctic Biology and Dept. of Biology and Wildlife, University of Alaska Fairbanks, ${ }^{4}$ Environmental Studies and Research Center (NEPAM), University of Campinas (UNICAMP) 
the ecosystem service metaphor (Chan et al. 2018), such as the idea of care (Jax et al. 2018, West et al. 2018).

More specific interpretations or applications of the concept of stewardship include environmental stewardship (Welchman 2012, Bennett et al. 2018), ecosystem stewardship (Chapin et al. 2010), and social-ecological stewardship (Cockburn et al. 2018). In this paper, we aim at investigating environmental initiatives to assess whether they can be framed as ecosystem stewardship, and if so, whether and how they address local social-ecological feedbacks that currently influence the quality of critical ecosystem services. The research was carried out at the Chapéu River Watershed, in the municipality of São Luiz do Paraitinga, Paraíba Valley, southeast Brazil.

\section{Study site and rationale}

The Paraíba Valley in São Paulo state (Fig. 1) is a promising setting for research on ecosystem-stewardship-related initiatives. This region, like many others in the country, has a history of landuse change involving the replacement of native Atlantic forest by different cultures, such as coffee in the 19th century, followed by cattle and rice (mostly along the Paraíba river) in the 20th century, and eucalyptus in the last four decades (São Paulo 2011). Currently, $71 \%$ of the valley's territory is composed of rural properties $(51 \%$ is pastureland and $32 \%$ is forest) while approximately $95 \%$ of the population resides in urban areas, some of them highly industrialized (Silva et al. 2017). In the last three decades, mostly because of socioeconomic factors, native forests have been regenerating in the valley, mainly on steep terrain, which is less suitable for agriculture (Farinaci and Batistella 2012, Silva et al. 2016, Bicudo da Silva et al. 2017). This process, known as forest transition, has taken place unintentionally as a result of economic marginalization of local agriculture, rural outmigration, and pastureland abandonment (Farinaci 2012, Silva et al. 2017). Strong historical heritage, strategic industries (e.g., oil, military, and aircraft), and technological research facilities highlight the importance of the valley nationally (São Paulo 2011). Also, its main river, the Paraíba, provides water to approximately 14 million people from two states, São Paulo and Rio de Janeiro (Agência Nacional de Águas 2019), although water availability has been decreasing for decades in São Paulo state (Marengo and Alves 2005).

Several environmental initiatives have flourished in the valley lately (Akarui 2017, Moraes 2019), and here we focus on those developed in São Luiz do Paraitinga. The municipality has approximately 10,000 inhabitants and comprises an area of 617 $\mathrm{km}^{2}$; the GDP is low compared to others in the state (550th position among 645 municipalities), the HDI is 0.697 (IBGE 2020), and its economy strongly relies on agricultural production (Akarui 2017). On 01 January 2010, São Luiz do Paraitinga experienced a major flood: its main river (the Paraitinga) rose 11 meters above its regular level in a matter of hours, due to high precipitation at the end of 2009 and factors linked to land degradation in its rural areas, like soil compaction and lack of native forests near watercourses (Akarui 2017, Moradei 2017). Many historical buildings were severely damaged, and part of the population was forced to temporarily abandon their homes. Since then, environmental initiatives, grounded in strong ties to the land and sense of place, have sought to ameliorate ecosystem services in the rural area and to improve local communities' livelihoods and minimize the risks of future floods (Akarui 2017, Moraes 2019). Many of these initiatives have encompassed the Chapéu River watershed, located in the rural area of the municipality, including a small village named Catuçaba. This watershed is an area of 20,620 hectares of hilly and steep landscape (Akarui 2017). The Chapéu River is $30 \mathrm{~km}$ long; it runs through several rural properties and through the village of Catuçaba, which concentrates most inhabitants of the watershed. Informal estimates for the village of Catuçaba accounts for approximately 800 inhabitants.

Fig. 1. The municipality of São Luiz do Paraitinga embedded in the Paraíba Valley (dark grey), southeast Brazil (Image by C. A. Islas).

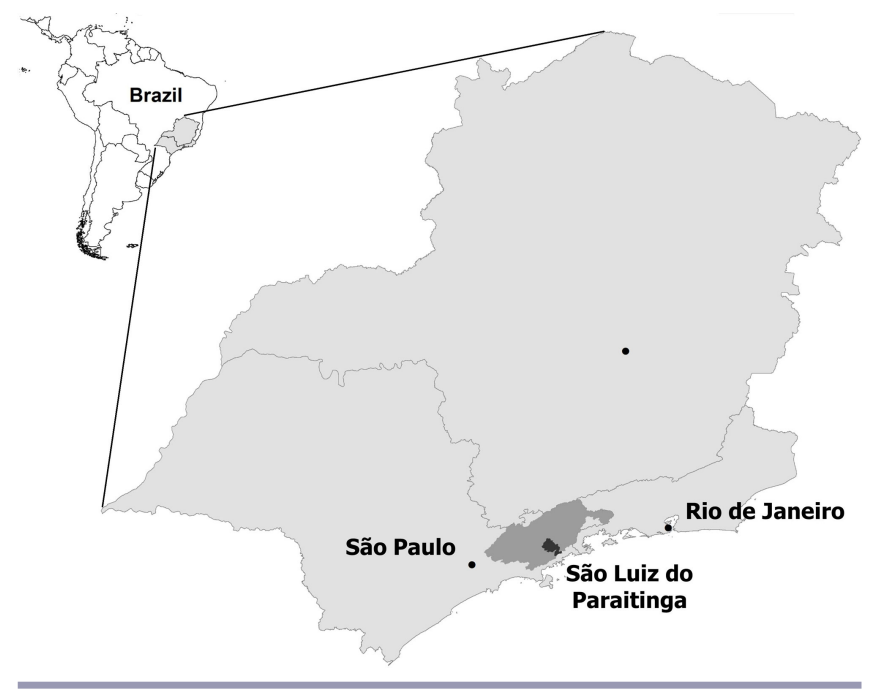

Our research focuses on the local level, at the Chapéu River watershed, which is considered a priority by the state government for restoration of riparian forests (Akarui 2017, Moraes 2019). The Chapéu River is the main tributary of the Paraitinga (the one that flooded in 2010) within the municipality. The Paraitinga runs into the Paraíba River; hence, on the regional level, we focus on the Upper Paraiba Valley, which encompasses the Paraitinga watershed and its sub-basins.

This study is part of a larger research project conducted in the above-mentioned territory, which sought to identify, through participatory methods, the ecosystem services that stakeholders considered most critical (i.e., the most important and, at the same time, the most vulnerable ones locally) and the feedbacks responsible for their condition. Moraes (2019) carried out 44 semistructured interviews with farmers/local residents, government staff, tourism entrepreneurs, and researchers who had previous knowledge about and some relationship (e.g., workplace, birthplace, residence) with the study site. Out of a list of 18 ecosystem services ${ }^{[1]}$ presented to them, they considered four ecosystem services critical in the watershed: water, food production, soil, and forests, the latter locally considered an ecosystem service per se. These were the most frequently mentioned ecosystem services, regardless of the stakeholder group. Out of these four services, only forests have been improving in the last 30 years, measured by an increase in forest cover. Water quality and quantity, food production, and soil are degrading 
because of both historical land use and management and existing feedbacks that reinforce this degradation. These feedbacks are mostly related to land use and management in the watershed.

From a resilience thinking perspective, a limited number of key variables and internal feedbacks interact and define the internal dynamics of a system, keeping it in a given stable state (Walker and Salt 2006, Chapin et al. 2009). Change in a system configuration involves change in feedbacks controlling it (Biggs et al. 2015). Although there are many environmental initiatives intended to improve the socio-environmental quality of the system both at local and regional levels, it is unclear if and how these initiatives would influence the operating feedbacks. Ecosystem stewardship is a suitable framework for such analysis, because its predominant approach is to manage feedbacks (Chapin et al. 2010).

\section{METHODS}

To achieve this paper's objectives, we developed an approach to assess ecosystem stewardship in practice. First, we identified all the environmental initiatives taking place in the territory of the Chapéu River watershed. Second, we selected the ones that matched the following criteria: (i) focus on at least one of the locally critical ecosystem services identified by locals, i.e., water, food, soil, and forest; (ii) ongoing project in place by the time of data collection; (iii) connection with the local community, i.e., if the community plays an active role in the initiative. Third, we analyzed whether the selected initiatives fit the criteria of the ecosystem-stewardship theoretical framework (Chapin et al. 2015):

1. Dual goals of ecosystem resilience, i.e., the capacity of ecosystems to sustain their functions and services despite disturbances, and human well-being in a broad sense (Díaz et al. 2015);

2. Integration of ecological and social processes across scales;

3. Emphasis on actions that shape the future instead of focusing on restoring the past.

\section{Data collection}

Data for this study were collected through direct and participant observation (Bernard 2006) at community and technical meetings and workshops, from July 2013 to August 2018. Previous projects that had been developed in the region since 2010 by members of our research team built trust with local stakeholders and organizations, facilitating our participation in such meetings. Direct observation was performed at 15 meetings of the "village community," a group of inhabitants of the rural district of Catuçaba, in the Chapéu River watershed. In these meetings, residents discussed a variety of subjects related to their everyday life, including environmentally friendly initiatives that they supported (Appendix 1). We were invited to those meetings when they coincided with our fieldwork. Additionally, we observed 16 technical meetings and workshops in the municipality of São Luiz do Paraitinga. These were specifically about government-led or NGO-led environmental projects in the Chapéu River watershed or at the larger Paraíba Valley and included experts and government staff that were connected to the projects (Appendix 2). We made direct observations at seven of those meetings and participated actively in the discussions, at the invitation of a key stakeholder, in nine meetings of technical working groups.
We supplemented observation data with data from nine unstructured interviews (Bernard 2006), from February 2015 to February 2017, with local leaders and key informants, people who were knowledgeable about the affairs of the local community or had particular competence in the history of local land use and social-ecological changes over time. Out of the nine key informants, four were rural smallholders born and raised at the watershed (including an elder), two were landowners and entrepreneurs living and working in the watershed for over 20 years, one was an agronomist owning land in the watershed, one was a local NGO staff member involved in participatory mapping processes developed with local rural inhabitants, and one was a local community leader.

Additionally, we reviewed grey literature (online and hardcopy material) regarding environmental projects, whenever available. Memo writing (Lempert 2007) performed throughout the whole period of research was helpful in developing insights and aiding the understanding about interactions and patterns observed in the social-ecological system.

\section{Data analysis}

Data collected for each selected initiative were transcribed, coded, and categorized, followed by data analysis (Seixas 2005, Bernard 2006). We first transcribed into Microsoft Word files the notes taken during or after the meetings and workshops, as well as the ones extracted from the supplementary material analyzed. For each transcription, we coded the respective data and organized them into one of the following categories: goals, premises, outcomes. Afterward, in order to assess whether each initiative could be framed as ecosystem-stewardship practices, we assessed whether the data fit into the key criteria of ecosystem stewardship described above. Finally, we qualitatively analyzed the data from the selected initiatives to verify if and how each one addressed the social-ecological feedbacks previously identified by Moraes (2019; see Table 1 for description of feedbacks), that currently affect critical ecosystem services in the social-ecological system.

\section{RESULTS}

Are there environmental initiatives at local and regional levels that contemplate the ecosystem stewardship criteria?

We identified 12 environmental initiatives (four state-led and eight community-based ones) taking place in our study site between 2013 and 2018, both at local (Chapéu River watershed) and regional (Paraíba Valley) levels. We also observed the development and activities of two stakeholder networks, which we regard as "environmental initiatives" as well (Fig. 2). Three out of these 14 initiatives were selected for this study because of their focus on locally critical ecosystem services and their fit to the ecosystem-stewardship criteria listed above. These were a community-level one, named "Village street market"; an environmental education project named "Our Paraitinga"; and "REDESUAPA," a network of regional-level influence acting as a bridging organization (sensu Berkes 2009). We present each of them below, briefly describing their history, goals, premises, expected or achieved outcomes, and level of action (summarized in Table 2). Afterwards we highlight how they match the key elements of the ecosystem-stewardship framework. 
Table 1. Current trend for the critical ecosystem services, the respective feedback mechanisms involved, and how they are being addressed by the environmental initiatives currently taking place in the Chapéu River watershed, São Luiz do Paraitinga municipality, southeast Brazil. REDESUAPA = Portuguese acronym for The Upper Paraíba River Sustainable Development Network.

\begin{tabular}{|c|c|c|c|}
\hline Ecosystem service $^{1}$ & Current trend $^{1}$ & Feedbacks involved in current trend ${ }^{1}$ & Initiatives addressing the feedbacks \\
\hline Water & $\begin{array}{l}\text { Siltation of watercourses; } \\
\text { decreasing infiltration in soil } \\
\text { and increased run-off }\end{array}$ & $\begin{array}{l}\text { Extensive grazing and overgrazed pastures } \\
\rightarrow \text { soil loss } \rightarrow \text { soil impoverishment } \rightarrow \text { low } \\
\text { fertility } \rightarrow \text { extensive grazing and } \\
\text { overgrazed pastures }\end{array}$ & $\begin{array}{l}\text { REDESUAPA fosters more sustainable management } \\
\text { practices by farmers (e.g., introducing trees in } \\
\text { pastures; pasture rotation) that prevent overgrazing } \\
\text { and soil loss. }\end{array}$ \\
\hline Soil & $\begin{array}{l}\text { Soil degradation (i.e., } \\
\text { decreased fertility) }\end{array}$ & & \\
\hline $\begin{array}{l}\text { Food } \\
\text { (farm crops) }\end{array}$ & Low production & $\begin{array}{l}\text { Lack of workforce } \rightarrow \text { low production } \rightarrow \\
\text { low income generation } \rightarrow \text { devaluation of } \\
\text { rural livelihoods } \rightarrow \text { outmigration } \rightarrow \text { lack } \\
\text { of workforce }\end{array}$ & $\begin{array}{l}\text { Village street market supports local small-scale } \\
\text { agricultural production (income generation). } \\
\text { REDESUAPA focuses on income generation for } \\
\text { smallholders through diversification of production } \\
\text { with more sustainable management practices. }\end{array}$ \\
\hline Food (livestock) & Low productivity & $\begin{array}{l}\text { Extensive grazing and overgrazed pastures } \\
\rightarrow \text { soil impoverishment } \rightarrow \text { low productivity } \\
\rightarrow \text { extensive grazing and overgrazed } \\
\text { pastures }\end{array}$ & $\begin{array}{l}\text { REDESUAPA fosters more sustainable management } \\
\text { practices by farmers, which lead to an increase in } \\
\text { productivity (e.g., introducing trees in pastures; } \\
\text { pasture rotation) }\end{array}$ \\
\hline Forest & Forest cover increase & $\begin{array}{l}\text { Decreased use of forest resources } \rightarrow \\
\text { erosion of knowledge and cultural } \\
\text { practices related to the forest } \rightarrow \text { decreased } \\
\text { use of forest resources }\end{array}$ & -- \\
\hline
\end{tabular}

Source: Moraes (2019).

${ }^{\dagger}$ latent feedback triggered by conditions that constrain the use of forest resources; this feedback mechanism is not causing the current trend.

Village street market (VSM)

The Village street market has been taking place almost every Saturday morning at the main square of Catuçaba district since April 2017. It is a community-based initiative organized by a group of inhabitants of Catuçaba district called the "Village Community." VSM was created to foster local agricultural production and to generate income for smallholders and artisans. It is a space for selling locally grown produce, artisanal foods, and crafts. The street market had been conceptualized by a few community members for many years. After participating from 2012 to 2015 in an outreach project led by a research group from the University of Campinas (Unicamp), Brazil, the villagers felt empowered to bring it to life: they self-organized and started VSM on their own. This initiative emerged as a response to the erosion of rural livelihoods and consequent scarcity of income generation options for the local community (Moraes and Islas 2020). Villagers do not have any support from private or public entities, thus developing the activities voluntarily. This probably explains the ups and downs experienced by VSM, whose activities were deeply affected by personal issues involving key stakeholders from the community and other participants of the VSM during 2018 and 2019 (discussed further in the text).

\section{Project "Our Paraitinga: waterwheel dialogues" (OP)}

This environmental education project was co-designed by a local non-governmental organization (NGO) named "Akarui" and staff from the Municipal Board of Education (including schoolteachers with multiple expertise). Akarui firstly conceptualized the project. This NGO is formed by residents of São Luiz do Paraitinga. Founded in 2003 in response to local land and sociocultural degradation, it has been developing projects and actions focusing on environmental conservation and local development mainly via public funding calls (Akarui 2019, Moraes and Islas 2020).
Paraitinga is the indigenous name of the river that flows across the municipality, which means "clear-water river." The objective of the project is to develop activities, e.g., workshops and field trips, with students of all local public schools to investigate and reflect upon the relationship of the local community with the river, as well as teaching material on the subject. This is intended to be a starting point for deeper reflections and discussions about their relationship with nature. The project involves all public schools (urban and rural) in the municipality. The ultimate goal is that such activities become part of the school curriculum after the end of the project (initially expected for 2020). The project was granted funding via a public call from the State Fund for Water Resources (Fehidro) in 2016 and began implementation in 2018. Setting common ground among all participants (NGO staff, schoolteachers, and principals) was a challenge that required some workshops conducted by an external facilitator.

\section{REDESUAPA}

REDESUAPA (Portuguese acronym for The Upper Paraíba River Sustainable Development Network) was formed after the 2010 flood. It started as one of the many working groups created by the municipal administration for the reconstruction efforts and gathered technical staff from the municipal and state government, local leaders, local and regional NGOs, and researchers. The objective was to avoid similar future disasters. Their actions initially focused on ameliorating environmental conditions (mainly related to soil and forests) in the rural areas of São Luiz do Paraitinga and neighboring municipalities. After the official end of the reconstruction period in 2013, the working group decided to continue working as REDESUAPA. In 2015, they realized the need to address social aspects in their projects, such as income generation for smallholders, and valuation of rural livelihoods. Its members meet voluntarily on a regular basis (twice or three times a year). REDESUAPA has designed and 
Fig. 2. Environmental initiatives affecting the Chapéu River (CR) watershed in São Luiz do Paraitinga municipality, southeast Brazil: RSD Project $=$ Rural Sustainable Development Project; Climate $\&$ Biodiversity Services $=$ Recovery and protection of climate and biodiversity services in the Paraíba do Sul basin of the Atlantic Forest of Brazil; TEEB-SP $=$ The Ecology and Economics of Biodiversity - São Paulo State; Restoration Assessment $=$ Restoration Opportunities Assessment $($ ROAM Methodology) in the Paraíba Valley, São Paulo State; REDESUAPA = The Upper Paraíba River Sustainable Development Network; Village community = the village community of Catuçaba; OP = Our Paraitinga project; VSM = Village Street Market; Waterfall = waterfall collective cleanup ("The Waterfall is Ours" movement); Trees = tree planting by the Chapéu River; Bamboo = bamboo planting along the Chapéu riverbank; Nut festival $=$ The Araucaria pine-nut festival; CR Watershed assessment $=$ Environmental Assessment of the Chapéu River watershed; CR Watershed restoration = Environmental Restoration of the Chapéu River Watershed. * = initiatives designed by or supported by REDESUAPA; ** = initiatives designed by the Village community.

State level (São Paulo state)

Supraregional level (Paraíba Valley+ other regions in the state)

Regional level (Paraíba Valley)

Municipal level (São Luiz do Paraitinga)

Local level (watershed)

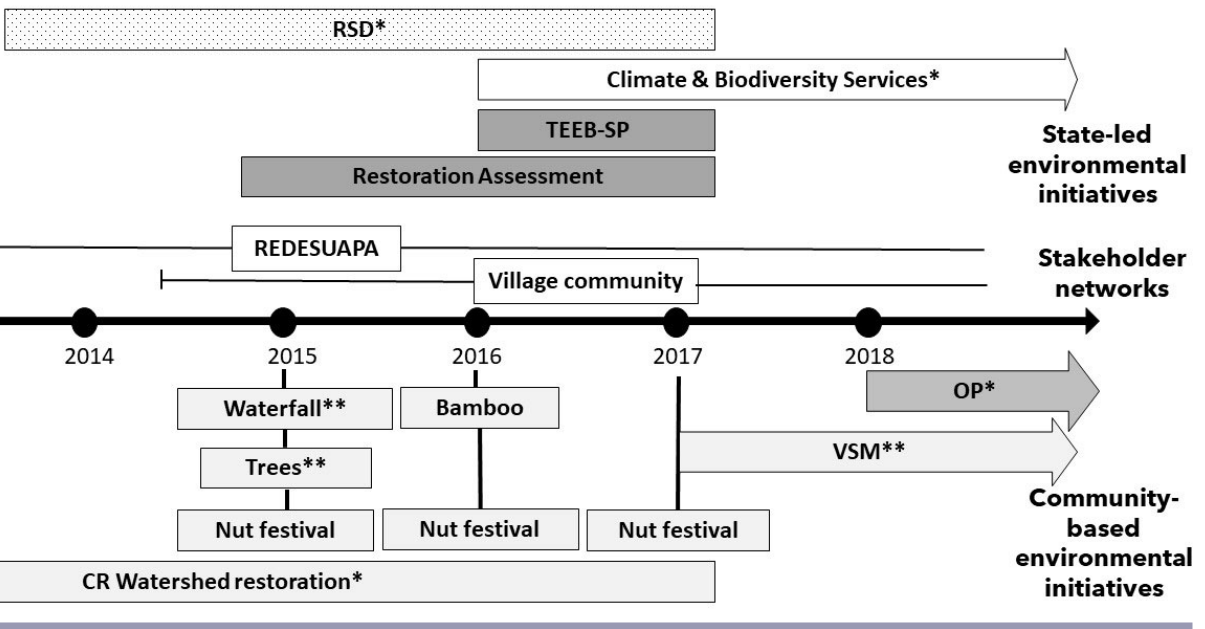

implemented projects focusing on conservation and restoration of soil and forests aligned with income generation for smallholders, where the main actions involve forest restoration, capacity building, and technical support for smallholders to adopt sustainable farming practices, i.e., agroforestry and silvopasture. Such practices provide environmental benefits (erosion control and prevention of river siltation) and represent an opportunity to increase the income for smallholders. REDESUAPA has worked to influence public policies as well. During the elections of 2016, they wrote an open letter to all candidates running for mayor, highlighting the importance of addressing sustainable development guidelines for the rural territory and asking the candidates to commit to them. The effects of REDESUAPA's actions transcend the municipality and have regional-level impacts (Moraes 2019). One example is the implementation of a major project called "Recovery and protection of climate and biodiversity services in the Paraíba do Sul basin of the Atlantic Forest of Brazil," funded by the Global Environmental Facility (GEF) through the Inter-American Development Bank (IDB).

\section{Connections among the three initiatives}

OP and VSM share two points of intersection: one individual that participated in the co-design of OP used to be a key member of the community of Catuçaba (and of VSM) until 2018, and one member of the local NGO occasionally participated in the VSM, selling homemade products. REDESUAPA and OP also share a member in common: one individual from the local NGO, who is connected to OP, used to participate regularly in the network meetings.
Can the initiatives analyzed be framed as ecosystem-stewardship practices?

The initiatives analyzed can be framed as ecosystem-stewardship practices because they encompass all key elements of this framework. According to our analysis, only REDESUAPA fully entails all elements, while VSM and OP partially address ecosystem resilience and the integration of ecological and social processes across scales (see Table 3 for details).

When comparing the data from the initiatives with the key socialecological feedbacks affecting critical ecosystem services in our study area identified by Moraes (2019), we verified that those feedbacks are addressed by at least one of the initiatives analyzed (Table 1). This finding reinforces the ecosystem-stewardship nature of these initiatives and raises reflections about the role and knowledge of local stakeholders in environmental initiatives, discussed in the following section. REDESUAPA addresses most feedbacks that are currently undermining water, soil, and food production in the Chapéu River catchment. VSM strictly addresses the feedback loop affecting agricultural production, and OP does not address any of the feedbacks previously identified, which is not necessarily a shortcoming, as we discuss later. More detailed description of ways that each initiative addresses each feedback loop are shown in Table 1.

\section{DISCUSSION}

How is ecosystem stewardship taking place in the territory?

Although "stewardship" is a key concept for sustainability (Cockburn et al. 2018, 2019), better links between theory and practice and more experimentation, and active learning about 
Table 2. Main aspects of three environmental initiatives impacting critical ecosystem services (i.e., water, food, soil, forests) in the Chapéu River watershed, São Luiz do Paraitinga municipality, southeast Brazil.

\begin{tabular}{|c|c|c|c|}
\hline & Village street market (VSM) & Our Paraitinga project (OP) & $\begin{array}{l}\text { The Upper Paraíba River Sustainable } \\
\text { Development Network (REDESUAPA) }\end{array}$ \\
\hline $\begin{array}{l}\text { Brief } \\
\text { description }\end{array}$ & $\begin{array}{l}\text { Weekly street market of locally grown } \\
\text { produce and other food items and } \\
\text { handmade crafts. }\end{array}$ & $\begin{array}{l}\text { Environmental education project co- } \\
\text { designed by a local non-profit organization } \\
\text { and the municipal board of education. }\end{array}$ & $\begin{array}{l}\text { Network involving various stakeholders who } \\
\text { meet voluntarily in the municipality. It focuses } \\
\text { on project development, creation of synergies } \\
\text { among diverse ongoing efforts. }\end{array}$ \\
\hline $\begin{array}{l}\text { Goals [targeted } \\
\text { ecosystem } \\
\text { services] }\end{array}$ & $\begin{array}{l}\text { To stimulate local small-scale agricultural } \\
\text { production and income generation for } \\
\text { local smallholders [food]. }\end{array}$ & $\begin{array}{l}\text { To transform the utilitarian perspective and } \\
\text { use of the Paraitinga River into a } \\
\text { relationship of care toward it [water]. } \\
\text { Capacity-building for environmental studies } \\
\text { in local schools. }\end{array}$ & $\begin{array}{l}\text { Conservation of the rural areas and income } \\
\text { generation for smallholders. } \\
\text { To promote sustainable management practices } \\
\text { of the soil and forests in rural areas and to } \\
\text { influence public policies for rural development } \\
\text { [soil, forests, food production]. }\end{array}$ \\
\hline $\begin{array}{l}\text { Premises and/ } \\
\text { or rationale }\end{array}$ & $\begin{array}{l}\text { Local agricultural production and } \\
\text { craftwork should be fostered and socially } \\
\text { valued as part of rural livelihoods. } \\
\text { Nowadays few people grow produce } \\
\text { locally, and there are people interested in } \\
\text { learning how to do it. }\end{array}$ & $\begin{array}{l}\text { The teacher as an agent of transformation. } \\
\text { Necessity of caring more about local water } \\
\text { resources and reflections on human-nature } \\
\text { relations within the local landscape. }\end{array}$ & $\begin{array}{l}\text { Prevention of disasters such as the } 2010 \text { flood. } \\
\text { The rural property is seen from a systemic } \\
\text { perspective (e.g., production and conservation } \\
\text { cannot be considered separately). }\end{array}$ \\
\hline $\begin{array}{l}\text { Expected or } \\
\text { achieved } \\
\text { outcomes }\end{array}$ & $\begin{array}{l}\text { Strengthening local production and social } \\
\text { relationships among community members. } \\
\text { Social valuation of local rural livelihood. }\end{array}$ & $\begin{array}{l}\text { Community awareness and empowerment } \\
\text { (students and families) about local } \\
\text { environmental aspects, including future } \\
\text { conservation actions. Knowledge co- } \\
\text { production. Development of learning tools } \\
\text { (e.g., booklets, brochures) to be used in } \\
\text { local public schools. }\end{array}$ & $\begin{array}{l}\text { Participation and empowerment of rural } \\
\text { communities. Integrated development (rural } \\
\text { and urban) that fosters citizen participation } \\
\text { and endorses local culture and rural livelihoods. } \\
\text { Positive influence on neighboring } \\
\text { municipalities. }\end{array}$ \\
\hline Level of action & $\begin{array}{l}\text { Local: rural areas around Catuçaba } \\
\text { village in the Chapéu River watershed. }\end{array}$ & $\begin{array}{l}\text { Municipal: urban and rural landscapes of } \\
\text { São Luiz do Paraitinga. }\end{array}$ & $\begin{array}{l}\text { Regional: São Luiz do Paraitinga and } \\
\text { neighboring municipalities. }\end{array}$ \\
\hline $\begin{array}{l}\text { Connection } \\
\text { with local } \\
\text { community }\end{array}$ & Community-based initiative. & $\begin{array}{l}\text { Co-designed by a local NGO, municipal } \\
\text { administration and schoolteachers. }\end{array}$ & $\begin{array}{l}\text { Local leaders, members of the local non-profit } \\
\text { organization, and of the municipal } \\
\text { administration are part of the network. }\end{array}$ \\
\hline Start & April 2017. & $\begin{array}{l}\text { Funding granted in 2016. Activities started } \\
\text { in } 2018 .\end{array}$ & 2010 \\
\hline
\end{tabular}

how it can be implemented are still needed (Bennett et al. 2018, Cockburn et al. 2018). Overcoming the lack of empirical data demonstrating how ecosystem stewardship is or can be applied on the ground can strengthen this framework as a feasible and practical approach to managing natural resources.

In general terms, most (if not all) community-based initiatives observed arose in response to land degradation and the erosion of rural livelihoods (Moraes and Islas 2020). State-led initiatives, in turn, took place mainly as a response to the 2010 flood that called the attention of higher level agencies to land degradation of rural landscapes. Regarding the three initiatives selected, our analysis indicates that ecosystem stewardship is being practiced in the Chapéu River watershed and beyond. All three initiatives were developed independently from any scientific framework, meaning that the ecosystem-stewardship elements arose from stakeholders' knowledge and expertise and from the way they understand, identify, care about, and relate to the local socialecological challenges. The initiatives ranged from local (VSM), to municipal (OP) and to regional-level perspectives (REDESUAPA). As a group, they act at multiple levels, having some cross-level interactions, and some redundancy in terms of the different elements of ecosystem stewardship that they address.

REDESUAPA is the only initiative that fully entails all ecosystem stewardship elements, probably because it was already born as a multi-stakeholder, interdisciplinary, cross-scale effort based on an empirical social-ecological resilience approach. The gathering of experts and local leaders with multiple backgrounds, working at different institutional levels (local, municipal, and state), with the clear purpose of focusing on actions that shape the future to transform the current state of the social-ecological system allowed for ecosystem-stewardship elements to be widely encompassed by the group in a natural way. The other two initiatives, however, display some gaps regarding specific stewardship elements. Both VSM and OP lack an explicit focus on ecological resilience, although they may favor it indirectly. For instance, the health of the local ecosystem can be enhanced if villagers encourage moresustainable farming practices, or if local raw materials (e.g., fibers of leaves that may be used for packaging or crafts) or fruits (e.g., juçara heart-of-palm fruits, Araucaria pine nuts) are used as a means to highlight the importance of local biodiversity. Similarly, the reflections and learning resulting from the activities entailed by OP can translate into action in favor of other water resources and riparian forests. Another shortcoming of VSM is that it does not integrate ecological and social processes across scales, and this is probably because the initiative was designed by the community to address strictly local issues, mainly concerning socioeconomic and cultural aspects. Nevertheless, we argue that the fact that not all elements of ecosystem stewardship are fully entailed by every initiative or project may be a minor issue. Because all of them overlap in space and time to some extent, they promote, as a group, complementary ecosystem-stewardship 
Table 3. Three environmental initiatives in the municipality of São Luiz do Paraitinga, southeast Brazil, encompassing the key elements of ecosystem stewardship (sensu Chapin et al. 2015). REDESUAPA = Portuguese acronym for The Upper Paraíba River Sustainable Development Network.

\begin{tabular}{|c|c|c|c|}
\hline & \multicolumn{3}{|c|}{ Key elements of ecosystem stewardship } \\
\hline & $\begin{array}{l}\# 1 \text { : (A) ecosystem resilience and (B) human } \\
\text { well-being }\end{array}$ & $\begin{array}{l}\text { \#2: integration of ecological and social } \\
\text { processes across scales }\end{array}$ & \#3: actions that shape the future \\
\hline $\begin{array}{l}\text { Village street market } \\
\text { (VMS) }\end{array}$ & $\begin{array}{l}\text { A: Partially, by fostering local small-scale } \\
\text { food production. Agriculture, however, can } \\
\text { be developed more sustainably (e.g., } \\
\text { organic, agroforestry). } \\
\text { B: Yes, by providing access to food and } \\
\text { adding value to local produce; } \\
\text { strengthening cultural identity, good social } \\
\text { relations. }\end{array}$ & $\begin{array}{l}\text { Partially. Agricultural production is part of } \\
\text { the rural livelihood and integrates ecological } \\
\text { aspects to social ones. It is mostly restricted } \\
\text { to the local level, although it occasionally } \\
\text { attracts outside buyers. }\end{array}$ & $\begin{array}{l}\text { Yes. It is a new livelihood option. } \\
\text { Current local food production is } \\
\text { mostly based on extensive cattle } \\
\text { raising and small vegetable gardens. }\end{array}$ \\
\hline $\begin{array}{l}\text { Our Paraitinga } \\
\text { (OP) }\end{array}$ & $\begin{array}{l}\text { A: Indirectly. The project focuses on } \\
\text { valuing the relationship with the river, } \\
\text { aiming at guiding future actions toward } \\
\text { fostering biodiversity and ecosystem } \\
\text { services. } \\
\text { B: Yes, through knowledge co-production } \\
\text { and exchange, community awareness about } \\
\text { environmental aspects and relational } \\
\text { values; cultural identity. }\end{array}$ & $\begin{array}{l}\text { Yes, as it focuses on social processes } \\
\text { (knowledge sharing and co-production) that } \\
\text { reflect on ecological ones (water quality and } \\
\text { ecosystem health). The organization intends } \\
\text { to hold periodic meetings with higher level } \\
\text { agencies (i.e., research institutes) and } \\
\text { REDESUAPA for technical and operational } \\
\text { support and knowledge exchange. }\end{array}$ & $\begin{array}{l}\text { Yes. The activities are going to be } \\
\text { incorporated into the local school } \\
\text { curriculum. Capacity building may } \\
\text { enable new initiatives in the future. } \\
\text { Community awareness and } \\
\text { empowerment about local } \\
\text { environmental aspects may trigger } \\
\text { change in how people relate to the } \\
\text { river and to nature. }\end{array}$ \\
\hline REDESUAPA & $\begin{array}{l}\text { A: Yes, as it focuses on the conservation } \\
\text { and improvement of the quality of } \\
\text { ecosystem services (e.g., soil, forests, food } \\
\text { production). } \\
\text { B: Yes, as it focuses on income generation } \\
\text { for smallholders, as well as on the increase } \\
\text { in their participation and empowerment. }\end{array}$ & $\begin{array}{l}\text { Yes, as it develops projects that address both } \\
\text { ecological and social processes. Systemic } \\
\text { perspective of rural areas: agriculture, } \\
\text { ecosystem health and socially valuing rural } \\
\text { livelihoods cannot be considered separately. } \\
\text { Its focus ranges from the rural property to } \\
\text { neighboring municipalities. }\end{array}$ & $\begin{array}{l}\text { Yes. Projects foster the adoption of } \\
\text { more sustainable management } \\
\text { practices in the rural areas, which } \\
\text { leads to the conservation of natural } \\
\text { resources. It works to influence public } \\
\text { policies regarding rural development, } \\
\text { which may lead to greater change. }\end{array}$ \\
\hline
\end{tabular}

practices in various levels in the territory, and such overlap (or redundancy) is important for social-ecological resilience (Biggs et al. 2012, Kotschy et al. 2015).

The initiatives emerged independently from one another and are not coordinated. Although they may (and perhaps should) continue to be developed autonomously, we argue that collaboration and coordination among them may enhance their impacts on the territory and act as a source of resilience in the face of disturbances. Collaboration is widely reported in the scientific literature of natural resources management and is suggested as a powerful means to catalyze stewardship (O'Farrell and Anderson 2010, Angelstam et al. 2013, Cockburn et al. 2018, $2020 a$ ). It is present under different management approaches, such as community-based natural resource management (Fernandez-Gimenez et al. 2008, Fabricius and Pereira 2015), comanagement (Kendrick 2003, Berkes 2009), and adaptive comanagement (Olsson et al. 2004, Armitage et al. 2009, Seixas et al. 2017). In our study case, we highlight two specific moments of collaboration among these projects: (i) when members of Akarui presented the OP project to the other members of REDESUAPA, asking for feedback and improvements before officially applying for funding; and (ii) when members of Akarui planned five meetings with REDESUAPA for technical and operational support for specific actions throughout this same project. We observed that the alignment between REDESUAPA and Akarui facilitated the implementation of state-led projects that depended on landowner inclusion: the good relationship between Akarui and some landowners (especially smallholders), cultivated for years, was decisive in overcoming smallholders' resistance to changing their practices, on one side, and, on the other, to enable the projects to meet their objectives.

The cross-level connections among the studied initiatives, by the individuals who participated in more than one initiative concomitantly, could facilitate collaboration in at least two ways: by (i) promoting the flow of information, expertise, and other resources from one initiative to another (e.g., similarly to how Akarui aided the implementation of environmental projects from the government), amplifying the possibilities of collective action (Adger 2003) and stewardship (Cockburn et al. 2020a); or (ii) by enabling (previously) connected social actors to gather in temporary working groups to address specific issues in the socialecological system (Olsson et al. 2007). In any case, active collaboration can foster the alignment of the initiatives (Heylighen 2013), which, in turn, may strengthen them by creating synergies and increasing social capital (Pretty and Ward 2001, Adger 2003), as well as fostering social learning, which is important for social-ecological resilience (Folke 2006, Biggs et al. 2012, Cundill et al. 2015).

In relation to the impacts of the initiatives on the feedbacks identified, we argue that they result from stakeholders' knowledge about system dynamics and systems thinking (mainly by some members of REDESUAPA and Akarui), and from the perception of social and environmental change locally (by Akarui and rural inhabitants). Although no one explicitly mentioned a feedback perspective when designing the actions, some of the people with technical background held a general understanding of feedback mechanisms (Appendix 2, "highlights \& quotes" column illustrates this). They were aware, for instance, of existing 
feedbacks between poverty and environmental degradation, and feedbacks between the lack of workforce for rural labor and decreased production and possibilities of income generation. Also, some of these individuals displayed remarkable knowledge and understanding of the dynamics of that social-ecological system. Other individuals were keen observers of proximate social and environmental change (especially degradation of rural livelihoods and of environmental aspects) and acted in response to that. Thus, we argue that the diversity of knowledge, i.e., technical, empirical, or local, among stakeholders involved in the initiatives, allied with systems-thinking skills and strong relational values (including care) toward the territory and its people, are ingredients that when combined may lead to lasting effects on the social-ecological system.

The initiatives that we analyzed operate at different dimensions with respect to the urgency and tangibility of the issues addressed. REDESUAPA and VSM respond to more pressing, tangible issues of the social-ecological system, e.g., food production, soil degradation, and water availability. OP focuses on deeper and intangible issues, such as feelings and relations, e.g., caring for the river, that, in time, are expected to unfold into transformed (or perhaps new) behavior and actions toward other people, the river, and nature itself. For this reason, although OP does not directly address any of the operating feedbacks identified, it probably holds greater potential to promote enduring change in the socialecological system. A multi-dimensional approach, where the cooccurrence of different ecosystem-stewardship practices, that concomitantly address pressing and non-urgent, however important, issues may enhance ecosystem stewardship and can be a potential pathway for social-ecological change toward sustainability. Besides co-occurrence of discrete initiatives in the same territory, some overlap among them, as discussed earlier, also matters. Likewise, active collaboration among initiatives may allow for stronger and synergistic effects on the feedbacks that are currently operating in the social-ecological system, especially regarding those addressed by more than one initiative, i.e., food from farm crops. Collaboration among multiple actors or initiatives holding different interests can be difficult in a territory (Cockburn et al. 2018). However, it may be fostered by a relational approach focusing on human-human relations, "sowing" the "social fabric" that enables stewardship (Cockburn et al. 2020a, b).

\section{Which salient ingredients shape local ecosystem stewardship and how are they combined into action?}

The actions related to each of the initiatives analyzed in this research result from the combination of at least three ingredients: care, relational values, and knowledge. All these ingredients have been previously linked to stewardship action (Jax et al. 2018, Peçanha Enqvist et al. 2018, West et al. 2018), as well as agency elsewhere (Peçanha Enqvist et al. 2018, Cockburn et al 2020a). Here we focus on how different arrangements of these three ingredients shaped ecosystem stewardship. Although we acknowledge that there are factors constraining people's agency in the initiatives investigated that are important to socialecological outcomes, this topic is beyond the scope of this study.

\section{Care}

Caring for other people, i.e., fellow villagers and rural inhabitants, is the main driving force of VSM. In this case, care translates into the willingness of a group of villagers to foster social valuation and appreciation for local production, by creating an opportunity for a new livelihood activity. Similarly, in the case of OP, caring for the river inspires action. The activities performed by this initiative are intended to transform the relationship of the whole community, starting with the youth, with the river, shifting from the dominant utilitarian perspective that alienates people from nature, by reviving their care toward it. Although care was not the main driver for REDESUAPA's actions at first, it later propelled them to innovate. Care nurtured by some members, both toward local smallholders and toward the land and the environment, led the network to embrace actions integrating environmental and social needs. REDESUAPA focused on providing support for smallholders to adopt sustainable farming practices that would yield environmental and economic benefits for themselves.

Expressions of care toward nature are connected to people's experiences in ecosystems, for example, as part of them (Leopold 1949, Schroeder 1996), and translate into environmentally friendly and/or conservation behavior (Bramston et al. 2010, Nassauer 2011, Tidball et al. 2018, Diver et al. 2019). Care highlights the importance of emotional connections and empathy as drivers for nature conservation (Jax et al. 2018). Although empathy per se may not be enough for triggering environmentally friendly behaviors, a combination of emotional connections, empathy, and action seem important for effective sustainability outcomes (Brown et al. 2019, Chapin 2020). In our study, care is present in all initiatives and permeates a multitude of socialecological relations, e.g., among people, between people and rural livelihoods, between people and the territory, people and the environment. More than an affective concern for the well-being of another, it is expressed as action (Jax et al. 2018), motivating people to do something in each case. Care is at the heart of two of the initiatives (VSM and OP) and enhances the other one (REDESUAPA), from the moment it is acknowledged as important. In all cases, care underpins a relational perspective that becomes central in sustaining the stewardship actions.

\section{Relational values}

Villagers consider VSM as a place where relational ties among people are built and strengthened, thus providing opportunity for people to reconnect to one another and to rural activities. Bonds between local community members used to be strongly influenced by agricultural practices. However, nowadays, "there are no 'buddies' to help with the crops," as stated by an elder. The importance of relational ties became evident when one key member of the community had to depart for personal reasons. This event destabilized the group. Although other community members kept the street market going, further problems involving miscommunication and misunderstanding between VSM members have arisen, dampening people's enthusiasm, and threatening its long-term existence. Building relations with the river and strengthening relations among community members, connected to one another by the river, are the focus of OP. In the case of REDESUAPA, care "prepared the ground" for a relational perspective that was later embraced to increase smallholders' interest and willingness to adopt sustainable farming practices. The network began organizing one-day field trips for knowledge exchange among smallholders. Also, some smallholders were invited to participate in specific meetings to 
share their perceptions with the technical staff from REDESUAPA. Over time, the network began to acknowledge the smallholders as partners, rather than just beneficiaries of their projects.

A relational perspective toward care frames it as part of the experiences and practices through which relations are built and transformed (West et al. 2018). All three initiatives analyzed focused on the relations among people, either reviving those that had weakened because of historical, contextual reasons (VSM and $\mathrm{OP}$ ) or creating opportunity for new relations to be built (REDESUAPA).

\section{Knowledge}

Besides nurturing relational ties, VSM is a stronghold congregating local knowledge and skills connected to agricultural production and craftsmanship, which have been historically eroded by out-migration and devaluation of rural livelihoods (Moraes and Islas 2020). Existing knowledge about the river is the means to demonstrate its importance to the community in the case of OP. Together with knowledge, the recognition of people's relationship to the river sensitizes the community to ways that the river is affected by human actions and behavior while empowering the community to transform its relationship with the river. Finally, knowledge permeates all the actions undertaken by REDESUAPA, acting as its main driving force since the beginning. Technical knowledge guided the first projects that aimed at reversing the degradation of surrounding rural areas after the 2010 flood. Five years later, empirical knowledge of the difficulties faced by local smallholders was decisive in highlighting the need to address economic and social issues side by side with environmental ones. All the initiatives contribute to the exchange of knowledge and new practices among participants and may even contribute to deepening human-nature relationships. In fact, both human-nature relationships and human-human relationships in nature matter for stewardship (Stenseke 2018, Cockburn et al. $2020 a, b)$.

Analogous to the proposition by West and colleagues (2018) where care, knowledge, and agency interact like "the interwoven strands of a rope," care, knowledge, and relational values supported one another in our study throughout the development of each initiative. Ecosystem stewardship seemed to be emerging from different combinations of these ingredients. Such understanding is especially important if we consider the need to address processes (including feedbacks) that slowly erode ecosystem quality and/or social relations. A relational approach toward forests, inspired by the OP initiative, would be especially beneficial to improving the quality of ecosystem services in our study site, as we discuss next.

\section{What happens when a salient ingredient is missing?}

The circumstances that favored the recent increase in forest cover regionally, together with the existence and local enforcement of legal restrictions preventing the use of forest resources by local communities, have triggered a silent feedback mechanism with likely negative future implications. The erosion of the knowledge related to the use of forest resources contributes to the separation between local communities and forest. Although this process relates primarily to the gradual loss of more utilitarian knowledge, it should be specifically addressed because it may disrupt some of the relational values between people and the forest. Because of this separation of the local community from the forest, a wide range of connections between them has weakened, from practical, everyday-life (e.g., knowledge about species and their use for specific ends) to cultural and subjective aspects (e.g., symbols, religious references, and leisure options). As a smallholder said, "When I was a child, we used to build wooden houses [to play] and used vines for that. Nowadays a boy rarely knows the types of vine. ... If I take my children into the forest, they won't know what types of vine there are. So, the culture of rural people has been fading, because you don't use that [knowledge] anymore. [Nowadays] instead of using a vine, you use a wire. The culture is ending." This quote highlights the connection between knowledge and relational values. The experiences that nurture a range of relational values that may foster stewardship practices towards the forest are being eroded, as well as these values themselves. Considering that relational values tend to be overshadowed by instrumental perspectives (Chan et al. 2016), weak connections (or relations) between people and forest may result in negative consequences for forest cover in the future. In a scenario where political, social, and/or economic drivers favor deforestation for short-term benefits, we wonder if the local community would stand up for their forests.

Local forests are already at risk. The whole biome (Atlantic Forest) is still under deforestation pressure (Rosa et al. 2021), despite legal instruments for its protection (Silva et al. 2016). At a regional level, these forests are imbedded in a context of high vulnerability to fire because of fragmentation and large areas covered by pastures (Guedes et al. 2020). Ecosystem-stewardship actions focusing on reconnecting local communities and forests are likely to safeguard the future of those forests and ensure, in the short term, the flux of a bundle of ecosystem services that depend directly on the existence of forests. Therefore, we argue that OP should explicitly include in its portfolio of information the importance of native forests for the river and the quality of water resources, as a means not only to raise awareness but also to promote people's reconnection to forests. Among the three initiatives, OP seems to be the one in which relational values are most explicitly addressed and embraced, focusing on deeper and intangible aspects of human-nature relations; therefore, OP has greater probability of causing deep and lasting impacts on the social-ecological system.

\section{CONCLUDING REMARKS}

To our knowledge, this paper is the first to demonstrate the workability of the ecosystem-stewardship framework to successfully assess environmental initiatives according to the respective elements proposed in the scientific literature. Our results highlight that ecosystem stewardship can arise out of local accurate perception by stakeholders of the issues affecting socialecological dynamics, independently from their knowledge system or background. This suggests therefore that ecosystem stewardship may be not only a deliberate application of a framework into practice but also an intuitive approach, emerging from ingredients of the social-ecological system, including care, relational values, and knowledge, and the way in which they interact in different contexts. By operationalizing the ecosystemstewardship framework, we present a pathway by which other initiatives can be assessed, hopefully contributing to an advance in scientific knowledge about ecosystem-stewardship practices throughout the world. 
The initiatives portrayed in this paper emerged independently from one another. A collective and multi-dimensional approach to stewardship, in which different initiatives overlap, to some extent, in time and space, and address a mix of pressing and nonurgent issues may be desirable. Collaborations among the initiatives have strengthened them and can eventually foster desired social-ecological transformations in the territory, by creating synergies and reducing the effects of the feedbacks responsible for the degradation of ecosystem services such as water, soil, and food production. Likewise, they can favor the design of joint efforts to address important unintended feedbacks, with special focus on relational values. This potentially increases when strong relational values between the local community and other elements of nature foster meaningful ecosystemstewardship practices, including toward local rivers and forests, consequently increasing the flux of ecosystem services in the short and long term.

[1] The list was developed based on the social and biophysical features of the study site, inspired by the categories proposed on the Millennium Ecosystem Assessment (2005) and other sources (TEEB 2010, CGIAR 2014).

Responses to this article can be read online at: https://www.ecologyandsociety.org/issues/responses. php/12417

\section{Acknowledgments:}

We thank the members of the Village community, REDESUAPA, the residents of São Luiz do Paraitinga, and Catuçaba village for their friendship, discussions, and inspiration; our colleagues from the CGCommons and LEME at the University of Campinas, from the CPS project at the University of Alaska Fairbanks (UAF). We thank Prof. Todd J. Brinkman (UAF) for the institutional and financial support. A. R. Moraes had financial support from the Brazilian Federal Agency for Support and Evaluation of Graduate Education-CAPES (finance code 001); C. S. Seixas had financial support from Community Conservation Research Network/SSHRC and FAPESP (process \#2015/19439-8). Cocen, Nepam, and the Graduate Program in Ecology, at the University of Campinas (UNICAMP), provided logistic and institutional support.

\section{Data Availability:}

The datalcode that support the findings of this study are available in Appendix 1 and 2.

\section{LITERATURE CITED}

Adger, W. N. 2003. Social capital, collective action, and adaptation to climate change. Economic Geography 79 (4):387-404.

Agência Nacional de Águas. 2019. Paraíba do Sul (saiba mais). Agência Nacional de Águas, Brasilia, Brasil. [online] URL: https://www.ana.gov.br/sala-de-situacao/paraiba-do-sul/paraibado-sul-saiba-mais

Akarui. 2017. Subsídios para um plano de restauração florestal da bacia do rio do Chapéu, São Luiz do Paraitinga, SP. Organização da Sociedade Civil de Interesse Público - Akarui, São Luiz do Paraitinga, São Paulo, Brazil.

Akarui. 2019. Sobre nós. Akarui - Associação para a Cultura, Meio Ambiente e Cidadania. São Luiz do Paraitinga, São Paulo, Brazil. [online] URL: https://www.akarui.org.br/

Angelstam, P., M. Elbakidze, R. Axelsson, M. Dixelius and J. Törnblom. 2013. Knowledge production and learning for sustainable landscapes: seven steps using social-ecological systems as laboratories. AMBIO 42:116-128. https://doi. org/10.1007/s13280-012-0367-1

Armitage, D. R., R. Plummer, F. Berkes, R. I. Arthur, A. T. Charles, I. J. Davidson-Hunt, A. P. Diduck, N. C. Doubleday, D. S. Johnson, M. Marschke, P. McConney, E. W. Pinkerton and E. K. Wollenberg. 2009. Adaptive co-management for socialecological complexity. Frontiers in Ecology and the Environment 7(2):95-102. https://doi.org/10.1890/070089

Baynes, J., J. Herbohn, C. Smith, R. Fisher and D. Bray. 2015. Key factors which influence the success of community forestry in developing countries. Global Environmental Change 35:226-238. https://doi.org/10.1016/j.gloenvcha.2015.09.011

Bennett, N. J., T. S. Whitty, E. Finkbeiner, J. Pittman, H. Bassett, S. Gelcich, and E. H. Allison. 2018. Environmental stewardship: a conceptual review and analytical framework. Environmental Management 61:597-614. https://doi.org/10.1007/s00267-017-0993-2

Berkes, F. 2009. Evolution of co-management: role of knowledge generation, bridging organizations and social learning. Journal of Environmental Management 90(5):1692-1702. https://doi.org/10.1016/ j.jenvman.2008.12.001

Berkes, F., and C. Folke. 1998. Linking social-ecological systems for resilience and sustainability. Pages 1-25 in F. Berkes, C. Folke, and J. Colding, editors. Linking social-ecological systems: management practices and social mechanisms for building resilience. Cambridge University Press, Cambridge, UK.

Bernard, H. R. 2006. Research methods in anthropology: qualitative and quantitative approaches. Fourth edition. AltaMira, Lanham, Maryland, UK.

Bicudo da Silva, R. F., M. Batistella, E. F. Moran, and D. Lu. 2017. Land changes fostering atlantic forest transition in Brazil: evidence from the Paraíba Valley. Professional Geographer 69 (1):80-93. https://doi.org/10.1080/00330124.2016.1178151

Biggs, R., M. Schlüter, D. Biggs, E. L. Bohensky, S. BurnSilver, G. Cundill, V. Dakos, T. M. Daw, L. S. Evans, K. Kotschy, A. M. Leitch, C. Meek, A. Quinlan, C. Raudsepp-Hearne, M. D. Robards, M. L. Schoon, L. Schultz, and P. C. West. 2012. Toward principles for enhancing the resilience of ecosystem services. Annual Reviews of Environment and Resources 37:421-448. https:// doi.org/10.1146/annurev-environ-051211-123836

Biggs, R., L. Gordon, C. Raudsepp-Hearne, M. Schlüter, and B. Walker. 2015. Principle 3: manage slow variables and feedbacks. 
Pages 105-141 in R. Biggs, M. Schlüter, and M. Schoon, editors. Principles for building resilience: sustaining ecosystem services in social-ecological systems. Cambridge University Press, Cambridge, UK. https://doi.org/10.1017/cbo9781316014240.006

Bramston, P., G. Pretty, and C. Zammit. 2010. Assessing environmental stewardship motivation. Environment and Behavior 43:776-788. https://doi.org/10.1177/0013916510382875

Brown, K., W. N. Adger, P. Devine-Wright, J. M. Anderies, S. Barr, F. Bousquet, C. Butler, L. Evans, N. Marshall, and T. Quinn. 2019. Empathy, place and identity interactions for sustainability. Global Environmental Change. 56:11-17. https://doi.org/10.1016/ j.gloenvcha.2019.03.003

CGIAR Research Program on Water, Land and Ecosystems (WLE). 2014. Ecosystem services and resilience framework. International Water Management Institute (IWMI), Colombo, Sri Lanka. CGIAR Research Program on Water, Land and Ecosystems (WLE). https://doi.org/10.5337/2014.229

Chan, K. M. A., P. Balvanera, K. Benessaiah, M. Chapman, S. Díaz, E. Gómez-Baggethun, R. Gould, N. Hannahs, K. Jax, S. Klain, G. W. Luck, B. Martín-López, B. Muraca, B. Norton, K. Ott, U. Pascual, T. Satterfield, M. Tadaki, J. Taggart, and N. Turner. 2016. Opinion: Why protect nature? Rethinking values and the environment. Proceedings of the National Academy of Sciences 113(6):1462-1465. https://doi.org/10.1073/pnas.1525002113

Chan, K. M., R. K. Gould, and U. Pascual. 2018. Editorial overview: relational values: what are they, and what's the fuss about? Current Opinion in Environmental Sustainability 35:A1A7. https://doi.org/10.1016/j.cosust.2018.11.003

Chapin III, F. S. 2020. Grassroots stewardship - sustainability within our reach. First edition. Oxford University Press, New York, New York, USA.

Chapin III, F. S., C. Folke, and G. P. Kofinas. 2009. A framework for understanding change. Pages 3-28 in F. S. Chapin, G. P. Kofinas, and C. Folke, editors. Principles of ecosystem stewardship: resilience-based natural resource management in a changing world. Springer Science + Business Media, New York, New York, USA. https://doi.org/10.1007/978-0-387-73033-2 1

Chapin III, F. S., S. R. Carpenter, G. P. Kofinas, C. Folke, N. Abel, W. C. Clark, P. Olsson, D. M. S. Smith, B. Walker, O. R. Young, F. Berkes, R. Biggs, J. M. Grove, R. L. Naylor, E. Pinkerton, W. Steffen, and F. J. Swanson. 2010. Ecosystem stewardship: sustainability strategies for a rapidly changing planet. Trends in Ecology \& Evolution 25(4):241-249. https://doi.org/10.1016/j. tree.2009.10.008

Chapin III, F. S., M. Sommerkorn, M. D. Robards, and K. Hillmer-Pegram. 2015. Ecosystem stewardship: a resilience framework for arctic conservation. Global Environmental Change 34:207-217. https://doi.org/10.1016/j.gloenvcha.2015.07.003

Cockburn, J., G. Cundill, S. Shackleton, and M. Rouget. 2018. Towards place-based research to support social-ecological stewardship. Sustainability 10(5):1434. https://doi.org/10.3390/ $\underline{\text { su10051434 }}$

Cockburn, J., G. Cundill, S. Shackleton, and M. Rouget. 2019. The meaning and practice of stewardship in South Africa. South
African Journal of Science 115(5/6):5339. https://doi. org/10.17159/sajs.2019/5339

Cockburn, J., G. Cundill, S. Shackleton, A. Cele, S. F. (A.) Cornelius, V. Koopman, J.-P. le Roux, N. McLeod, M. Rouget, S. Schroder, D. Van den Broeck, D. R. Wright, and M. Zwinkels. 2020a. Relational hubs for collaborative landscape stewardship. Society \& Natural Resources 33:681-693. https://doi. org/10.1080/08941920.2019.1658141

Cockburn, J., E. Rosenberg, A. Copteros, S. F. (A.) Cornelius, N. Libala, L. Metcalfe, and B. van der Waal. 2020b. A relational approach to landscape stewardship: towards a new perspective for multi-actor collaboration. Land 9(7):224. https://doi. org/10.3390/land 9070224

Cundill, G., A. M. Leitch, L. Schultz, D. Armitage, and G. Peterson. 2015. Principle 5: encourage learning. Pages 174-200 in R. Biggs, M. Schlüter, and M. L. Schoon, editors. Principles for building resilience: sustaining ecosystem services in socialecological systems. Cambridge University Press, Cambridge, UK. https://doi.org/10.1017/cbo9781316014240.008

Díaz, S., S. Demissew, J. Carabias, C. Joly, M. Lonsdale, N. Ash, A. Larigauderie, J. R. Adhikari, S. Arico, A. Báldi, A. Bartuska, I. A. Baste, A. Bilgin, E. Brondizio, K. M. Chan, V. E. Figueroa, A. Duraiappah, M. Fischer, R. Hill, T. Koetz, P. Leadley, P. Lyver, G. M. Mace, B. Martin-Lopez, M. Okumura, P. Pacheco, U. Pascual, E. S. Pérez, B. Reyers, E. Roth, O. Saito, R. J. Scholes, N. Sharma, H. Tallis, R. Thaman, R. Watson, T. Yahara, Z. A. Hamid, C. Akosim, Y. Al-Hafedh, R. Allahverdiyev, E. Amankwah, S. T. Asah, Z. Asfaw, G. Bartus, L. A. Brooks, J. Caillaux, G. Dalle, D. Darnaedi, A. Driver, G. Erpul, P. EscobarEyzaguirre, P. Failler, A. M. M. Fouda, B. Fu, H. Gundimeda, S. Hashimoto, F. Homer, S. Lavorel, G. Lichtenstein, W. A. Mala, W. Mandivenyi, P. Matczak, C. Mbizvo, M. Mehrdadi, J. P. Metzger, J. B. Mikissa, H. Moller, H. A. Mooney, P. Mumby, H. Nagendra, C. Nesshover, A. A. Oteng-Yeboah, G. Pataki, M. Roué, J. Rubis, M. Schultz, P. Smith, R. Sumaila, K. Takeuchi, S. Thomas, M. Verma, Y. Yeo-Chang, and D. Zlatanova. 2015. The IPBES conceptual framework - connecting nature and people. Current Opinion in Environmental Sustainability 14:1-16. https:// doi.org/10.1016/j.cosust.2014.11.002

Diver, S., M. Vaughan, M. Baker-Médard, and H. Lukacs. 2019. Recognizing "reciprocal relations" to restore community access to land and water. International Journal of the Commons 13 (1):400-429. https://doi.org/10.18352/ijc.881

Fabricius, C., and T. Pereira. 2015. Community biodiversity inventories as entry points for local ecosystem stewardship in a South African communal area. Society \& Natural Resources 28:1030-1042. https://doi.org/10.1080/08941920.2015.1014591

Farinaci, J. S. 2012. The new forests of São Paulo State: a multiscale study using the forest transition theory perspective. Dissertation. Universidade Estadual de Campinas, Campinas, Brazil. [online] URL: http://repositorio.unicamp.br/jspui/handle/REPOSIP/280732

Farinaci, J. S., and M. Batistella. 2012. Variação na cobertura vegetal nativa em São Paulo: um panorama do conhecimento atual. Revista Árvore 36(4):695-705. https://doi.org/10.1590/ $\underline{\mathrm{s} 0100-67622012000400011}$ 
Fernandez-Gimenez, M. E., H. L. Ballard, and V. E. Sturtevant. 2008. Adaptive management and social learning in collaborative and community-based monitoring: a study of five communitybased forestry organizations in the western USA. Ecology and Society 13(2):4. https://doi.org/10.5751/ES-02400-130204

Folke, C. 2006. Resilience: the emergence of a perspective for social-ecological systems analyses. Global Environmental Change 16(3):253-267. https://doi.org/10.1016/j.gloenvcha.2006.04.002

Guedes, B. J., K. G. Massi, C. Evers, and M. Nielsen-Pincus. 2020. Vulnerability of small forest patches to fire in the Paraiba do Sul River Valley, southeast Brazil: implications for restoration of the Atlantic Forest biome. Forest Ecology and Management 465:118095. https://doi.org/10.1016/j.foreco.2020.118095

Heylighen, F. 2013. Self-organization in communicating groups: the emergence of coordination, shared references and collective intelligence. Pages 117-149 in À. Massip-Bonet and A. BastardasBoada, editors. Complexity perspectives on language, communication and society. Springer-Verlag, Berlin, Germany. https://doi.org/10.1007/978-3-642-32817-6 10

Instituto Brasileiro de Geografia e Estatística (IBGE). 2020. São Luiz do Paraitinga - Panorama. IBGE, Rio de Janeiro, State of Rio de Janeiro, Brazil. [online] URL: https://cidades.ibge.gov.br/ brasil/sp/sao-luiz-do-paraitinga/panorama

Jax, K., M. Calestani, K. M. Chan, U. Eser, H. Keune, B. Muraca, L. O'Brien, T. Potthast, L. Voget-Kleschin, and H. Wittmer. 2018. Caring for nature matters: a relational approach for understanding nature's contributions to human well-being. Current Opinion in Environmental Sustainability 35:22-29. https:// doi.org/10.1016/j.cosust.2018.10.009

Kendrick, A. 2003. Caribou co-management in northern Canada: fostering multiple ways of knowing. Pages 241-267 in F. Berkes, J. Colding, and C. Folke, editors. Navigating social-ecological systems: building resilience for complexity and change. Cambridge University Press, Cambridge, UK. https://doi.org/10.1017/ CBO9780511541957.015

Kotschy, K., R. Biggs, T. Daw, C. Folke and P. C. West. 2015. Principle 1: maintain diversity and redundancy. Pages 50-79 in R. Biggs, M. Schlüter, and M. L. Schoon, editors. Principles for building resilience: sustaining ecosystem services in socialecological systems. Cambridge University Press, Cambridge, UK. https://doi.org/10.1017/cbo9781316014240.004

Krasny, M. E., and K. G. Tidball. 2012. Civic ecology: a pathway for earth stewardship in cities. Frontiers in Ecology and the Environment 10(5):267-273. https://doi.org/10.1890/110230

Krasny, M. E., P. Silva, C. Barr, Z. Golshani, E. Lee, R. Ligas, E. Mosher, and A. Reynosa. 2015. Civic ecology practices: insights from practice theory. Ecology and Society 20(2):12. https://doi. org/10.5751/ES-07345-200212

Lempert, L. B. 2007. Asking questions of the data: memo writing in the grounded theory tradition. Pages 245-264 in A. Bryant and K. Charmaz, editors. The SAGE handbook of grounded theory. SAGE, London, UK. https://doi.org/10.4135/9781848607941. $\underline{\mathrm{n} 12}$
Leopold, A. 1949. A sand county almanac and sketches here and there. Special commemorative edition. Oxford University Press, New York, New York, USA.

Marengo, J. A., and L. M. Alves. 2005. Tendências hidrológicas da bacia do rio Paraíba do Sul. Revista Brasileira de Meteorologia 20(2):215-226.

Mathevet, R., F. Bousquet, and C. M. Raymond. 2018. The concept of stewardship in sustainability science and conservation biology. Biological Conservation 217:363-370. https://doi. org/10.1016/j.biocon.2017.10.015

Millennium Ecosystem Assessment. 2005. Ecosystems and human well-being: synthesis. Island, Washington, D.C., USA.

Moradei, N. S. 2017. The major flood of the São Luiz do Paraitinga 2010. Thesis. Universidade de São Paulo, São Paulo, Brazil. https://doi.org/10.11606/D.16.2017.tde-02032017-113404

Moraes, A. R. 2019. Ecosystem services in a hilly rural landscape: contributions for resilience-based management. Dissertation. Universidade Estadual de Campinas, Campinas, Brazil. [online] URL: http://repositorio.unicamp.br/jspui/handle/REPOSIP/338484

Moraes, A. R., and C. A. Islas. 2020. Community responses to historical land degradation: lessons from São Luiz do Paraitinga, Brazil. Pages 363-379 in M. Arce-Ibarra, M. R. P. Vázquez, E. B. Baltazar, and L. G. Araujo, editors. Socio-environmental regimes and local visions: transdisciplinary experiences in Latin America. Springer, Cham, Switzerland. https://doi.org/10.1007/978-3-030$\underline{-49767-5 \quad 18}$

Nassauer, J. I. 2011. Care and stewardship: from home to planet. Landscape and Urban Planning 100(4):321-323. https://doi. org/10.1016/j.landurbplan.2011.02.022

O'Farrell, P. J., and P. M. Anderson. 2010. Sustainable multifunctional landscapes: a review to implementation. Current Opinion in Environmental Sustainability 2(1-2):59-65. https://doi. org/10.1016/j.cosust.2010.02.005

Olsson, P., C. Folke, and F. Berkes. 2004. Adaptive comanagement for building resilience in social-ecological systems. Environmental Management 34:75-90. https://doi.org/10.1007/s00267-003-0101-7

Olsson, P., C. Folke, V. Galaz, T. Hahn, and L. Schultz. 2007. Enhancing the fit through adaptive co-management: creating and maintaining bridging functions for matching scales in the Kristianstads Vattenrike Biosphere Reserve Sweden. Ecology and Society 12(1):28. https://doi.org/10.5751/es-01976-120128

Peçanha Enqvist, J., S. West, V. A. Masterson, L. J. Haider, U. Svedin, and M. Tengö. 2018. Stewardship as a boundary object for sustainability research: linking care, knowledge and agency. Landscape and Urban Planning 179:17-37. https://doi. org/10.1016/j.landurbplan.2018.07.005

Pretty, J., and H. Ward. 2001. Social capital and the environment. World Development 29(2):209-227. https://doi.org/10.1016/ S0305-750X(00)00098-X

Raymond, C. M., M. Reed, C. Bieling, G. M. Robinson, and T. Plieninger. 2016. Integrating different understandings of landscape stewardship into the design of agri-environmental 
schemes. Environmental Conservation 43(4):350-358. https://doi. org/10.1017/S037689291600031X

Rosa, M. R., P. H. S. Brancalion, R. Crouzeilles, L. R. Tambosi, P. R. Piffer, F. E. B. Lenti, M. Hirota, E. Santiami, and J. P. Metzger. 2021. Hidden destruction of older forests threatens Brazil's Atlantic Forest and challenges restoration programs. Science Advances 7(4):eabc4547. https://doi.org/10.1126/sciadv. $\underline{\mathrm{abc} 4547}$

São Paulo. 2011. Subsídios ao planejamento ambiental da unidade hidrográfica de gerenciamento de recursos hídricos Paraíba do Sul: UGRHI 02. Secretaria do Meio Ambiente, São Paulo, Brazil.

Saxena, A. K., D. Chatti, K. Overstreet, and M. R. Dove. 2018. From moral ecology to diverse ontologies: relational values in human ecological research, past and present. Current Opinion in Environmental Sustainability 35:54-60. https://doi.org/10.1016/j. cosust.2018.10.021

Schroeder, H. W. 1996. Ecology of the heart: understanding how people experience natural environments. Pages 13-27 in A. W. Ewert, editor. Natural resource management: the human dimension. Westview Press, Boulder, Colorado, USA.

Seixas, C. S. 2005. Abordagens e técnicas de pesquisa participativa em gestão de recursos naturais. Pages 73-111 in P. F. Vieira, F. Berkes, and C. S. Seixas, editors. Gestão integrada e participativa de recursos naturais: conceitos, métodos e experiências. Secco, Florianópolis, Brazil.

Seixas, C. S., A. C. E. Dias, and R. R. Freitas. 2017. Navigating from government-centralised management to adaptive comanagement in a marine protected area, Paraty, Brazil. Pages 157-180 in D. Armitage, A. Charles, and F. Berkes, editors. Governing the coastal commons: communities, resilience and transformation. Routledge, New York, New York, USA. https:// doi.org/10.4324/9781315688480-9

Silva, R. F. B., M. Batistella, and E. F. Moran. 2016. Drivers of land change: human-environment interactions and the Atlantic forest transition in the Paraíba Valley, Brazil. Land Use Policy 58:133-144. https://doi.org/10.1016/j.landusepol.2016.07.021

Silva, R. F. B., M. D. A. Rodrigues, S. A. Vieira, M. Batistella, and J. S. Farinaci. 2017. Perspectives for environmental conservation and ecosystem services on coupled rural-urban systems. Perspectives in Ecology and Conservation 15(2):74-81. https://doi.org/10.1016/j.pecon.2017.05.005

Stenseke, M. 2018. Connecting 'relational values' and relational landscape approaches. Current Opinion in Environmental Sustainability 35:82-88. https://doi.org/10.1016/i.cosust.2018.10.025

The Economics of Ecosystems \& Biodiversity (TEEB). 2010. Mainstreaming the economics of nature: a synthesis of the approach, conclusions and recommendations of TEEB. TEEB, Geneva, Switzerland. [online] URL: http://www.teebweb.org/wpcontent/uploads/Study $\% 20$ and $\% 20$ Reports/Reports/Synthesis $\% 20$ report/ TEEB $\% 20$ Synthesis $\% 20$ Report $\% 202010$.pdf

Tidball, K. G., S. Metcalf, M. Bain, and T. Elmqvist. 2018. Community-led reforestation: cultivating the potential of virtuous cycles to confer resilience in disaster disrupted social- ecological systems. Sustainability Science 13:797-813. https://doi. org/10.1007/s11625-017-0506-5

Walker, B., and D. Salt. 2006. Resilience thinking: sustaining ecosystems and people in a changing world. Island, Washington, D.C., USA.

Welchman, J. 2012. A defence of environmental stewardship. Environmental Values 21(3):297-316. https://doi.org/10.3197/096$\underline{327112 X 13400390125975}$

West, S., L. J. Haider, V. Masterson, J. P. Enqvist, U. Svedin, and M. Tengö. 2018. Stewardship, care and relational values. Current Opinion in Environmental Sustainability 35:30-38. https://doi. org/10.1016/j.cosust.2018.10.008 
Appendix 1. Environmental initiatives by the village community of Catuçaba, São Luiz do Paraitinga municipality, Brazil, between July 2013 and August 2018.

\begin{tabular}{|c|c|c|c|c|}
\hline $\begin{array}{l}\text { Initiative } \\
\text { (year) }\end{array}$ & Level & $\begin{array}{l}\text { Issues encompassed } \\
\text { by each initiative }\end{array}$ & $\begin{array}{l}\text { Ecosystem } \\
\text { services affected } \\
\text { by the initiative }\end{array}$ & $\begin{array}{c}\text { Context (necessities/concerns } \\
\text { raised by villagers) }\end{array}$ \\
\hline $\begin{array}{l}\text { The } \\
\text { waterfall is } \\
\text { ours } \\
(2015)\end{array}$ & Local & $\begin{array}{l}\text { Waterfall cleanup } \\
\text { effort by the } \\
\text { community. } \\
\text { Production and } \\
\text { installation of signs by } \\
\text { the waterfall, to } \\
\text { highlight/raise } \\
\text { awareness about its } \\
\text { importance to the local } \\
\text { community (e.g., for } \\
\text { leisure, fun, relaxation, } \\
\text { spiritual connection) } \\
\text { and the necessity of } \\
\text { caring for it. }\end{array}$ & $\begin{array}{l}\text { Water quality; } \\
\text { recreation and } \\
\text { tourism; } \\
\text { inspiration for art } \\
\text { and culture; } \\
\text { mental health } \\
\text { benefits; spiritual } \\
\text { benefits }\end{array}$ & $\begin{array}{l}\text { The property where the waterfall } \\
\text { is located was for sale; villagers } \\
\text { were worried that the eventual } \\
\text { buyer might prevent public } \\
\text { access to the waterfall, especially } \\
\text { in face of signs of abandonment } \\
\text { (mainly garbage left behind). } \\
\text { Villagers raised the need to } \\
\text { sensitize not only the local } \\
\text { community but also the eventual } \\
\text { property buyer to the local } \\
\text { cultural importance of the } \\
\text { waterfall. }\end{array}$ \\
\hline $\begin{array}{l}\text { Tree } \\
\text { planting by } \\
\text { the river } \\
(2015)\end{array}$ & Local & $\begin{array}{l}\text { Tree planting by the } \\
\text { Chapéu river, at } \\
\text { Catuçaba village. }\end{array}$ & $\begin{array}{l}\text { Water quality; } \\
\text { erosion control; } \\
\text { recreation and } \\
\text { tourism (due to } \\
\text { scenic view) }\end{array}$ & $\begin{array}{l}\text { The riverbanks at the village } \\
\text { were being eroded away, } \\
\text { endangering houses and people. } \\
\text { Some villagers also said that the } \\
\text { "riverbanks should be } \\
\text { embellished with more trees". }\end{array}$ \\
\hline $\begin{array}{l}\text { Village } \\
\text { street } \\
\text { market } \\
(2017- \\
\text { nowadays) }\end{array}$ & Local & $\begin{array}{l}\text { Fostering and } \\
\text { strengthening of local } \\
\text { small-scale agricultural } \\
\text { production. }\end{array}$ & $\begin{array}{l}\text { Farm crops, } \\
\text { inspiration for } \\
\text { culture (cultural } \\
\text { identity) }\end{array}$ & $\begin{array}{l}\text { The street market was conceived } \\
\text { by villagers in order to } \\
\text { reestablish and socially value } \\
\text { local produce and artisanal food } \\
\text { (i.e., cheese, bread, cake, jams) } \\
\text { as part of the local rural } \\
\text { livelihood. } \\
\text { Villagers acknowledged the } \\
\text { street market as a place for } \\
\text { sharing and strengthening } \\
\text { cultural identity and relationships } \\
\text { among community members. The } \\
\text { market also provides incentive } \\
\text { for local production. }\end{array}$ \\
\hline
\end{tabular}


Appendix 2. Technical meetings and workshops observed between July 2013 and August 2018 in São Luiz do Paraitinga, Brazil.

\begin{tabular}{|c|c|c|c|c|c|}
\hline $\begin{array}{l}\text { Types of } \\
\text { meetings } \\
\text { observed }\end{array}$ & $\begin{array}{l}\text { Main } \\
\text { participants }\end{array}$ & $\begin{array}{l}\text { Environmental } \\
\text { project(s) } \\
\text { discussed }\end{array}$ & $\begin{array}{l}\text { Ecosystem } \\
\text { services } \\
\text { targeted / } \\
\text { discussed }\end{array}$ & $\begin{array}{l}\text { Examples of } \\
\text { needs } \\
\text { identified }\end{array}$ & \begin{tabular}{|l|} 
Examples of \\
main highlights \\
\& quotes
\end{tabular} \\
\hline $\begin{array}{l}\text { REDESUAPA } \\
8 \text { meetings } \\
\text { Feb } 2015 \text { - } \\
\text { Aug } 2018\end{array}$ & $\begin{array}{l}\text { Municipal } \\
\text { government; } \\
\text { state agencies } \\
\text { (environment; } \\
\text { agriculture; } \\
\text { forestry; rural } \\
\text { extension); } \\
\text { ENGOs } \\
\text { (regional and } \\
\text { local). }\end{array}$ & $\begin{array}{l}\text { (i) Sustainable } \\
\text { rural } \\
\text { development } \\
\text { program (state- } \\
\text { led). } \\
\text { (ii) Rural } \\
\text { territorial } \\
\text { development } \\
\text { program (state- } \\
\text { led). } \\
\text { (iii) "Our } \\
\text { Paraitinga" - } \\
\text { environ. } \\
\text { education } \\
\text { project (ENGO- } \\
\text { led). } \\
\text { (iv) Recovery } \\
\text { and protection } \\
\text { of climate and } \\
\text { biodiversity } \\
\text { services (state- } \\
\text { led). }\end{array}$ & $\begin{array}{l}\text { Food } \\
\text { production } \\
\text { (crops and } \\
\text { livestock); } \\
\text { water } \\
\text { regulation; } \\
\text { soil } \\
\text { fertility; } \\
\text { habitat for } \\
\text { native } \\
\text { species; } \\
\text { micro- } \\
\text { climate } \\
\text { regulation; } \\
\text { raw } \\
\text { materials; } \\
\text { recreation } \\
\text { and } \\
\text { tourism; } \\
\text { soil } \\
\text { fertility; } \\
\text { forests. }\end{array}$ & $\begin{array}{l}\text { - To improve } \\
\text { the dialogue } \\
\text { with } \\
\text { smallholders; } \\
\text { - How to deal } \\
\text { with } \\
\text { smallholders' } \\
\text { reluctance to } \\
\text { embrace new } \\
\text { approaches } \\
\text { concerning } \\
\text { milk } \\
\text { production? } \\
\text { - How to } \\
\text { engage } \\
\text { smallholders in } \\
\text { the projects? } \\
\text { - The need to } \\
\text { reconcile } \\
\text { different } \\
\text { visions of } \\
\text { conservation } \\
\text { with 'rural } \\
\text { sustainable } \\
\text { development'. }\end{array}$ & $\begin{array}{l}\text { "We need to } \\
\text { consider the rural } \\
\text { property as a } \\
\text { whole, we should } \\
\text { not neglect the } \\
\text { smallholder" } \\
\text { (state agricultural } \\
\text { agent); } \\
\text { "Smallholders } \\
\text { need to be heard } \\
\text { about what they } \\
\text { want to grow" } \\
\text { (state forestry } \\
\text { manager); } \\
\text { "We're working } \\
\text { on this territory } \\
\text { to change it" } \\
\text { (local ENGO); } \\
\text { "REDESUAPA } \\
\text { has made us } \\
\text { much stronger" } \\
\text { (local ENGO) } \\
\text { "Future projects } \\
\text { will be built } \\
\text { upon what's } \\
\text { been done so far" } \\
\text { (state agricultural } \\
\text { agent); } \\
\text { "[Our Paraitinga] } \\
\text { project goes } \\
\text { beyond } \\
\text { environmental } \\
\text { education itself. } \\
\text { It is not meant to } \\
\text { be temporary, } \\
\text { but permanent" } \\
\text { (local ENGO). }\end{array}$ \\
\hline $\begin{array}{l}\text { Workshops } \\
\text { related to } \\
\text { environmental } \\
\text { projects } \\
6 \text { meetings }\end{array}$ & $\begin{array}{l}\text { Municipal } \\
\text { government; } \\
\text { state agencies } \\
\text { (environment; } \\
\text { agriculture; } \\
\text { forestry; rural }\end{array}$ & $\begin{array}{l}\text { (i) Restoration } \\
\text { of the Chapéu } \\
\text { river watershed } \\
\text { (ENGO-led). } \\
\text { (ii) Restoration } \\
\text { opportunities in }\end{array}$ & $\begin{array}{l}\text { Food } \\
\text { production } \\
\text { (crops and } \\
\text { livestock); } \\
\text { water } \\
\text { regulation; }\end{array}$ & $\begin{array}{l}\text { - The local } \\
\text { cultural pattern } \\
\text { that prevents } \\
\text { smallholders } \\
\text { from } \\
\text { embracing new }\end{array}$ & $\begin{array}{l}\text { People started } \\
\text { working together } \\
\text { after the flood } \\
(2010) \text {. } \\
\text { "The state } \\
\text { environmental }\end{array}$ \\
\hline
\end{tabular}




\begin{tabular}{|c|c|c|c|c|c|}
\hline $\begin{array}{l}\text { Jan } 2016- \\
\text { Nov } 2017\end{array}$ & $\begin{array}{l}\text { extension; } \\
\text { technological } \\
\text { research); } \\
\text { ENGOs } \\
\text { (regional and } \\
\text { local); } \\
\text { National } \\
\text { Institute for } \\
\text { Space } \\
\text { Research; } \\
\text { civil society. }\end{array}$ & $\begin{array}{l}\text { the Paraíba } \\
\text { Valley of São } \\
\text { Paulo State } \\
\text { (state-led). }\end{array}$ & $\begin{array}{l}\text { erosion } \\
\text { control; } \\
\text { soil } \\
\text { fertility; } \\
\text { habitat for } \\
\text { native } \\
\text { species. }\end{array}$ & $\begin{array}{l}\text { farming } \\
\text { activities and } \\
\text { participating in } \\
\text { rural } \\
\text { development } \\
\text { projects. } \\
\text { - The need to } \\
\text { optimize } \\
\text { restoration } \\
\text { efforts. } \\
\text { - The need for } \\
\text { an action plan } \\
\text { with the state } \\
\text { government for } \\
\text { forest } \\
\text { restoration. } \\
\text { - The need for } \\
\text { diversity of } \\
\text { approaches (no } \\
\text { "one size fits } \\
\text { all” solution). }\end{array}$ & $\begin{array}{l}\text { agency has never } \\
\text { been that close to } \\
\text { the state } \\
\text { agricultural } \\
\text { agency as now" } \\
\text { (state agricultural } \\
\text { agent); } \\
\text { "We need to end } \\
\text { this trap, where } \\
\text { poverty leads to } \\
\text { environmental } \\
\text { degradation, } \\
\text { which leads to } \\
\text { poverty, which } \\
\text { leads to } \\
\text { degradation." } \\
\text { (state } \\
\text { environmental } \\
\text { agent); } \\
\text { "The crisis } \\
\text { [generated by the } \\
\text { 2010 flood and } \\
\text { drought in 2013] } \\
\text { favored greater } \\
\text { proximity among } \\
\text { different } \\
\text { agencies" (state } \\
\text { environmental } \\
\text { agent); } \\
\text { "Currently it is } \\
\text { easier to restore } \\
\text { native forests } \\
\text { than } 20 \text { years } \\
\text { ago" (state rural } \\
\text { extension } \\
\text { officer); } \\
\text { "The idea of } \\
\text { 'rural sustainable } \\
\text { development' } \\
\text { emerged from } \\
\text { our experience" } \\
\text { (local ENGO). }\end{array}$ \\
\hline $\begin{array}{l}\text { Public } \\
\text { presentations } \\
\text { of } \\
\text { environmental } \\
\text { projects } \\
3 \text { meetings }\end{array}$ & $\begin{array}{l}\text { State agencies } \\
\text { (environment; } \\
\text { agriculture; } \\
\text { forestry; rural } \\
\text { extension); } \\
\text { ENGOs } \\
\text { (international; } \\
\text { regional; }\end{array}$ & $\begin{array}{l}\text { (i) Integrated } \\
\text { analysis of land } \\
\text { use and } \\
\text { ecosystem } \\
\text { services in the } \\
\text { Paraitinga river } \\
\text { basin (state-led). } \\
\text { (ii) TEEB SP } \\
\text { (state-led). }\end{array}$ & $\begin{array}{l}\text { Livestock } \\
\text { production; } \\
\text { water } \\
\text { regulation; } \\
\text { erosion } \\
\text { control; soil } \\
\text { fertility; } \\
\text { habitat for } \\
\text { native }\end{array}$ & $\begin{array}{l}\text { - The need to } \\
\text { identify critical } \\
\text { ecosystem } \\
\text { services; } \\
\text { - The need to } \\
\text { foster } \\
\text { economic } \\
\text { activities while } \\
\text { taking into }\end{array}$ & $\begin{array}{l}\text { The } \\
\text { environmental } \\
\text { projects } \\
\text { previously } \\
\text { developed in the } \\
\text { Paraíba Valley } \\
\text { created favorable } \\
\text { conditions for }\end{array}$ \\
\hline
\end{tabular}




\begin{tabular}{|l|l|l|l|l|l|}
\hline Oct 2014- & $\begin{array}{l}\text { local); } \\
\text { Nov } 2017 \\
\text { civil society; } \\
\text { private } \\
\text { environmental } \\
\text { research } \\
\text { institute. }\end{array}$ & $\begin{array}{l}\text { (iii) Recovery } \\
\text { and protection } \\
\text { of climate and } \\
\text { biodiversity } \\
\text { services (state- } \\
\text { led). }\end{array}$ & $\begin{array}{l}\text { species; } \\
\text { water } \\
\text { regulation. }\end{array}$ & $\begin{array}{l}\text { account } \\
\text { conservation } \\
\text { priority areas; } \\
- \text { The need to } \\
\text { successfully } \\
\text { implement } \\
\text { environmental } \\
\text { projects in the } \\
\text { region (a role } \\
\text { model for } \\
\text { other parts of } \\
\text { the country). }\end{array}$ & $\begin{array}{l}\text { other projects to } \\
\text { be implemented. }\end{array}$ \\
\end{tabular}

